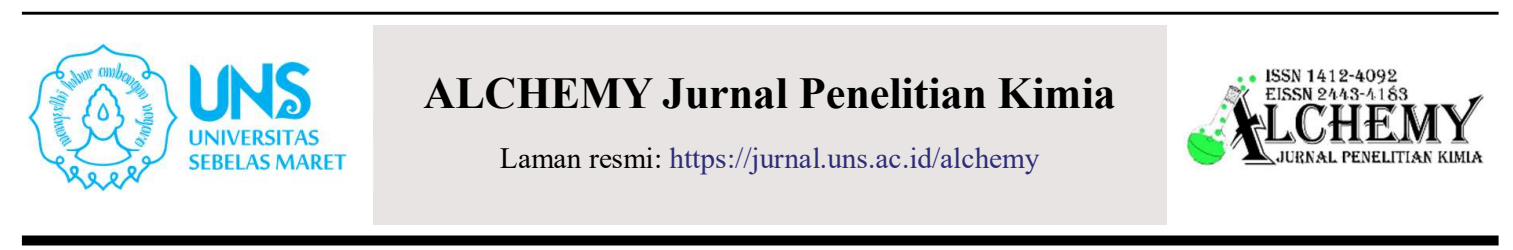

\title{
Pengaruh Bentonit terhadap Pembentukan Fasa Polimorf dan Sifat Termal Membran
} Hibrida Poliviniliden Fluorida/Bentonit

\author{
Edi Pramono $^{a^{*}}$, Rosid Eka Mustofa ${ }^{a}$, Ozi Adi Saputra ${ }^{a}$, Yulianto Adi Nugrohob ${ }^{b}$ Deana Wahyunigrum ${ }^{c}$, \\ Cynthia Linaya Radiman ${ }^{d}$, Sayekti Wahyuningsiha, Teguh Endah Saraswatia, Sentot Budi Rahardjo ${ }^{a}$, \\ Witri Wahyu Lestaria ${ }^{a}$ Dian Maruto Widjonarko ${ }^{a}$, Ari Handono Ramelan ${ }^{\mathrm{e}}$ \\ a Prodi Kimia, FMIPA, Universitas Sebelas Maret, Jl. Ir. Sutami 36 A, Kentingan Surakarta 57126, Indonesia

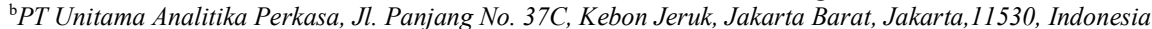 \\ ${ }^{c}$ Devisi Kimia Organik, FMIPA, Institut Teknologi Bandung, Jl. Ganesa 10 Bandung 40132, Indonesia \\ ${ }^{\mathrm{d} D e v i s i}$ Kimia Fisika dan Anorganik, FMIPA, Institut Teknologi Bandung, Jl. Ganesa 10 Bandung 40132, Indonesia

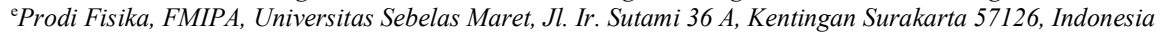 \\ "Corresponding author: edi.pramono.uns@staff.uns.ac.id \\ DOI: 10.20961/alchemy.17.2.46136.177-184
}

Received 29 November 2020, Accepted 11 August 2021, Published 09 September 2021

Kata kunci:

analisis termal; bentonit; inversi fasa; membran hibrida; poliviniliden fluorida-PVDF.

Keywords:

thermal analysis; bentonite; phase inversion; hybrid membran; polyvinylidene fluoride-PVDF.
ABSTRAK. Kajian struktur dan degradasi termal pada membran hibrida poliviniliden fluorida (PVDF)/lempung bentonit (BNT) telah dilakukan. Penelitian ini bertujuan mengetahui pengaruh penambahan BNT terhadap pembentukan fasa PVDF dan sifat termalnya. Membran hibrida $\mathrm{PVDF} /$ lempung BNT dibuat dengan metode inversi fasa. Membran yang dihasilkan dikarakterisasi dengan attenuated total reflectance fourier transform infrared (ATR-FTIR), x-ray diffraction (XRD), dan differential scanning calorimetry (DSC). Hasil penelitian menunjukkan membran PVDF/BNT memiliki struktur polimorf PVDF fasa $\alpha$ dan $\beta$ yang terkonfirmasi dari data FTIR dan XRD. Data DSC menunjukkan penurunan nilai titik leleh $(\mathrm{Tm})$ dengan penambahan BNT, dan dengan rentang suhu pelelehan yang lebih kecil. Kristalisasi PVDF terjadi secara isothermal dan adanya BNT menghasilkan titik kristalisasi (Tc) pada suhu yang lebih tinggi dibandingkan membran PVDF murni. Analisis termal dengan DSC memberikan informasi komprehensif pelelehan dan kristalisasi dari polimorf PVDF pada matriks membran.

\begin{abstract}
Effect of Bentonite toward Polymorph Phase Formation and Thermal Properties of Polyvinylidene Fluoride/Bentonite Hybrid Membranes. The study of the structure and thermal properties of PVDF/bentonite (BNT) hybrid membranes has been carried out. This study aims to determine the effect of BNT addition on the phase formation and thermal properties of the PVDF. In this study, PVDF/BNT hybrid membranes were prepared through the phase inversion method. The resulting membrane was characterized by Attenuated Total Reflectance Fourier Transform Infrared (ATR-FTIR), $x$-ray diffraction (XRD), and differential scanning calorimetry (DSC). The results showed that the PVDF/BNT membrane has a PVDF polymorph structure with $\alpha$ and $\beta$ phases confirmed by FTIR and XRD data. The DSC data showed that the addition of BNT decrease of the melting point (Tm) and with a smaller melting temperature range. PVDF polymorph crystallization occurs isothermally and the presence of BNT produces a crystallization point $(\mathrm{Tc})$ at a higher temperature than pristine PVDF membrane. Thermal analysis with DSC provides comprehensive information on melting and crystallization of PVDF polymorphs in the membrane matrix.
\end{abstract}

\section{PENDAHULUAN}

Teknologi membran berbasis polimer sintetik saat ini mengalami perkembangan yang cukup pesat. Teknologi membran banyak diaplikasikan pada bidang pengolahan air maupun energi (Ahmadian-Alam and Mahdavi, 2018; Lee et al., 2017; Park et al., 2015). Polisulfon (PSf) dan Poliviniliden Fluorida (PVDF) merupakan polimer sintetik yang cukup banyak diaplikasikan pada teknologi tersebut (Polisetti and Ray, 2021; Yuan et al., 2019; Zhu et al., 2020). PVDF dipilih sebagai material membran karena beberapa keunggulan yang dimilikinya yaitu ketahanan kimia, sifat termal, dan ketahanan mekanik yang tinggi (Santos et al., 2008).

Kinerja membran PVDF dalam beberapa aplikasinya ditentukan oleh struktur polimorf yang terbentuk pada membran. Secara umum, PVDF stabil pada struktur fasa $\alpha, \beta$, dan y (Fadaei et al., 2014; Zheng et al., 2007). Perbedaan tersebut terjadi pada penataan atom fluorin pada rantai polimer seperti ditujukkan pada Gambar 1, yaitu $\alpha$-PVDF berstruktur Trans (T) dan Gauce (G) secara berurutan atau TGTGTG', $\beta$-PVDF berstruktur T atau TTTTTT', dan y-PVDF berstruktur T3GT3G (Ruan et al., 2018). Dari ketiga struktur tersebut diketahui bahwa $\beta$ - 
PVDF bersifat polar, sementara $\alpha$ dan y-PVDF bersifat nonpolar (Cui et al., 2015; Zheng et al., 2007). Perbedaan kepolaran tersebut memberikan kinerja yang berbeda dalam aplikasinya seperti konduktivitas dan permeabilitas air (Pramono et al., 2019; Seraji and Guo, 2020). Kajian tentang pembentukan fasa kristal PVDF yang dipengaruhi oleh jenis pelarut, sonikasi dan kondisi koagulasi telah dikaji sebelumnya (Ike et al., 2017; Tao et al., 2013). Penambahan senyawa aditif tertentu pada membran PVDF dapat meningkatkan kinerja membran dan penelitian sebelumnya melaporkan bahwa adanya senyawa organik hidrofilik maupun oksida pada membran PVDF mempengaruhi pembentukan fasa $\beta$ (Lai et al., 2015; Seraji and Guo, 2020). Pramono et al. (2019) melaporkan bahwa penambahan BNT pada membran PVDF meningkatkan fasa $\beta$ dan hidrofilisitas permukaan membran. Pembentukan fasa polimorf PVDF pada struktur membran dapat dikaji dengan analisis fourier transform infrared (FTIR), $x$-ray diffraction (XRD) dan analis termal dengan differential scanning calorimetry (DSC). Analisis mendalam fasa polimorf membran PVDF dengan FTIR telah dilaporkan oleh peneliti sebelumnya (Cai et al., 2017), namun kajian tentang pengaruh penambahan oksida lempung terhadap pembentukan fasa polimorf membran PVDF menggunakan analisis termal belum banyak dilakukan.

Penelitian ini mempelajari pengaruh penambahan lempung Bentonit (BNT) pada pembentukan struktur polimorf segmen PVDF (Gambar 1) dalam membran dan sifat termalnya. Penelitian ini bertujuan untuk mengetahui pengaruh BNT terhadap pembentukan fasa polimorf PVDF serta pengaruhnya pada proses pelelehan dan kristalisasi PVDF. Membran dibuat melaui proses inversi fasa dan dikarakterisasi strukturnya dengan XRD dan ATR-FTIR. Pelelehan dan kristalisasi membran hibrida dianalisis dengan DSC.

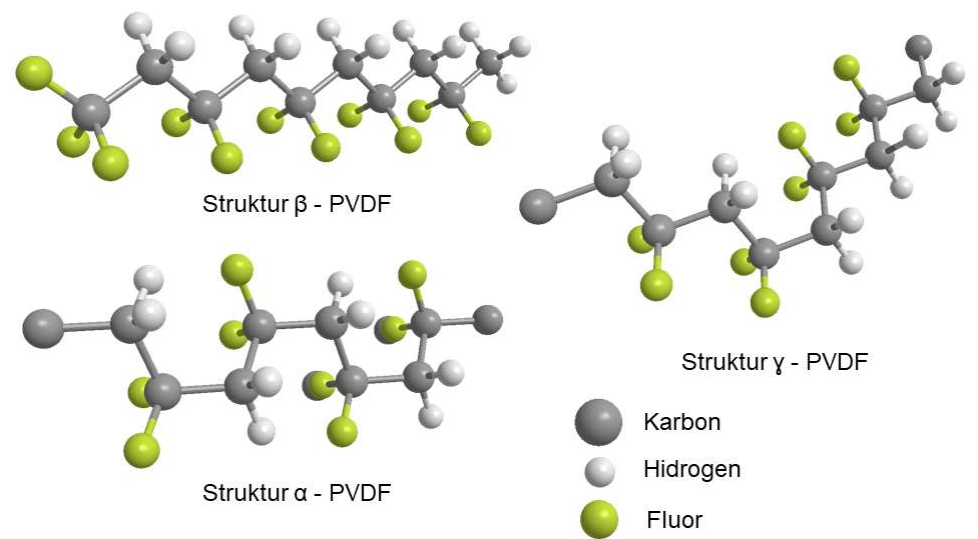

Gambar 1. Struktur polimorf PVDF.

\section{METODE PENELITIAN}

Beberapa bahan yang digunakan pada penelitian ini antara lain Bentonit (BNT-Bratachem Indonesia), dimetil formamida-DMF (PA grade - Merck), PEG400 (PA Grade-Merck), PVDF MW 535.000 g/mol (Solef ${ }^{\circledR} 1015$ ). Sebelum pemakaian BNT diayak dengan ukuran 180 mesh.

\section{Pembuatan Membran Hibrida}

Membran hibrida PVDF/BNT dibuat dengan metode inversi fasa mengikuti publikasi sebelumnya (Pramono et al., 2019). Larutan cetak membran disiapkan dengan melarutkan polimer PVDF, PEG400 dan BNT dengan konsentrasi PVDF 18\%, PEG 4\% dan BNT divariasikan 1 - 5\% (b/b) dalam DMF. Larutan diaduk pada suhu penangas minyak silikon $60{ }^{\circ} \mathrm{C}$ selama 24 jam sampai homogen yaitu tidak terbentuk endapan lempung. Dalam kondisi panas, larutan dilapiskan di atas permukaan kaca $\left(20 \times 30 \mathrm{~cm}^{2}\right)$ dan langsung dimasukkan dalam bak koagulan yang berisi air. Membran padat yang terbentuk dilepas dari kaca dan dicuci dengan air mengalir selama 24 jam. Pada penelitian ini diperoleh membran padat dengan rata-rata ketebalan $0,08 \mathrm{~mm}$.

\section{Analisis Gugus Fungsi dan Kristal Membran PVDF}

Analisis gugus fungsi dan keberadaan fasa PVDF dilakukan dengan attenuated total reflectance fourier transform infrared (ATR-FTIR - Carry 630). Membran dipotong dengan dimensi $2 \times 2 \mathrm{~cm}^{2}$ dan dikeringkan pada suhu $60^{\circ} \mathrm{C}$ selama 24 jam. Sampel kering di-scan permukaannya dengan ATR-FTIR sebanyak 48 scan. Sementara itu struktur matrik membran PVDF dianalis dengan $x$-ray diffraction (XRD Rigaku). Sebelum pengukuran 
membran dikeringkan dan dilekatkan pada sampel sel. Membran dianalisis dengan XRD pada $2 \theta 0,2^{\circ}$ sampai $60^{\circ}$. Hasil yang diperoleh diolah dengan perangkat lunak Origin 2017.

\section{Analisis Termal Membran Hibrida}

Analisis termal membran hibrida menggunakan alat simultaneous thermal analyzer (STA) LINSEIS PT1600. Sebelum analisis dilakukan, alat dikalibrasi terlebih dahulu menggunakan standar Indium dengan titik leleh 156 ${ }^{\circ} \mathrm{C}$. Pengukuran STA dilakukan dengan thermocouple TGA-DSC tipe $\mathrm{S}$ dengan cawan krus alumina dan atmosfer udara. Setelah semua file kalibrasi dan zero siap, sampel membran dibakar pada kecepatan pemanasan 10 derajat permenit (dpm) pada rentang suhu $25{ }^{\circ} \mathrm{C}-250{ }^{\circ} \mathrm{C}$, dan dilanjutkan pendinginan alat sampai kembali ke suhu ruang. Perekaman data dilakukan pada pemanasan sampai $250^{\circ} \mathrm{C}$ untuk menghasilkan informasi titik leleh, dan pendinginan untuk mendapatkan informasi titik kristalisasi. Data yang diperoleh dievaluasi dengan perangkat lunak STA Linseis PT1600 dan analisis lanjut dilakukan dengan perangkat lunak Origin 2017.

\section{HASIL DAN PEMBAHASAN}

\section{Analisis Struktur Polimorf PVDF}

Secara umum diketahui bahwa PVDF stabil dalam tiga fasa yaitu $\alpha, \beta$, dan $\gamma$. Untuk mengetahui keberadaan polimorf PVDF dalam berbagai fasa dilakukan analisis dengan XRD dan ATR-FTIR. Difraktogram XRD yang dihasilkan ditunjukkan pada Gambar 2. Data menunjukkan bahwa serbuk polimer PVDF yang digunakan pada penelitian ini memiliki satu fasa yaitu $\alpha$-PVDF yang terkonfirmasi pada $2 \theta 17,9^{\circ}$ dan $19,6^{\circ}$ (Bai et al., 2012; Ruan et al., 2018; Tsonos et al., 2015). Kemunculan fasa $\beta$ PVDF terkonfirmasi pada difraktogram membran PVDF maupun hibridanya yaitu munculnya puncak khas pada $20,46^{\circ}$. Pada penelitian ini, membran dibuat dengan pelarut DMF dan menghasilkan membran dengan fasa campuran $\alpha$-PVDF dan $\beta$-PVDF yang terkonfirmasi dari puncak pada $18,66^{\circ}$ untuk fasa $\alpha$ dan $20,46^{\circ}$ untuk fasa $\beta$. Proses kristalisasi fasa PVDF dalam membran dipengaruhi oleh jenis pelarut yang digunakan. Interaksi dipolar pelarut dan PVDF mengakibatkan terjadinya transformasi susunan $\mathrm{CH}_{2}-\mathrm{CF}_{2}$, dan sifat polar pada media pelarut maupun koagulan mengakibatkan pembentukan konformasi fasa $\beta$ (Tao et al., 2013).

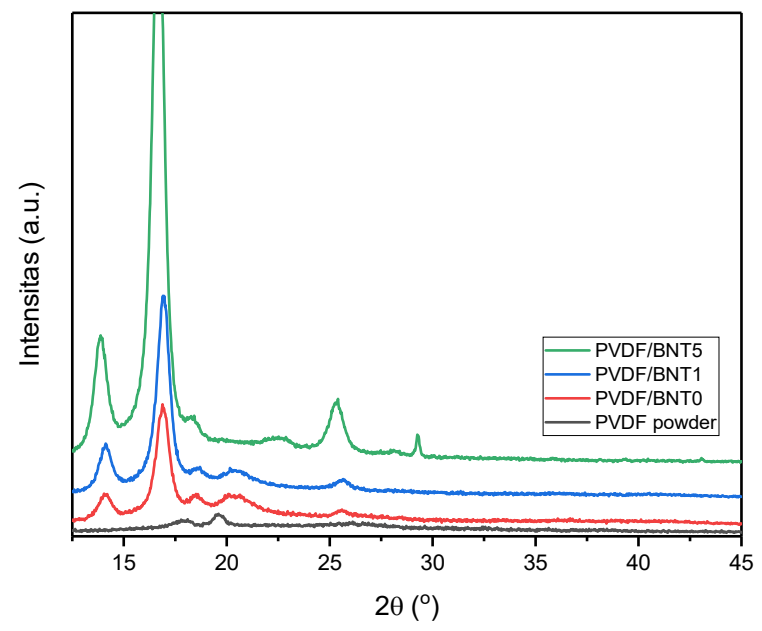

Gambar 2. Difraktogram serbuk PVDF dan membran hibrida PVDF/BNT.

Pembentukan fasa $\alpha$-PVDF dan $\beta$-PVDF dikonfirmasi pula dengan analisis FTIR yang ditunjukkan pada Gambar 3. Data ATR-FTIR powder PVDF menunjukkan munculnya puncak pada $762 \mathrm{~cm}^{-1}, 795 \mathrm{~cm}^{-1}$ dan $974 \mathrm{~cm}^{-}$ ${ }^{1}$ yang berkorelasi dengan vibrasi $\mathrm{C}-\mathrm{C}, \mathrm{C}-\mathrm{F}$ dan $\mathrm{C}-\mathrm{H}$ pada fasa $\alpha \mathrm{PVDF}$, dan tidak ditemukan puncak fasa $\beta$ PVDF. Sementara itu fasa $\alpha$-PVDF dan $\beta$-PVDF terkonfirmasi untuk seluruh membran hibrida yaitu dengan adanya tambahan puncak baru pada bilangan gelombang $840 \mathrm{~cm}^{-1}$ (Cui et al., 2015; Ike et al., 2017) yang berasal dari vibrasi C-F (Bai et al., 2012) fasa $\beta-P V D F$. Data tersebut menyimpulkan bahwa membran yang dihasilkan memiliki fasa campuran antara fasa $\alpha-P V D F$ dan $\beta$-PVDF. 


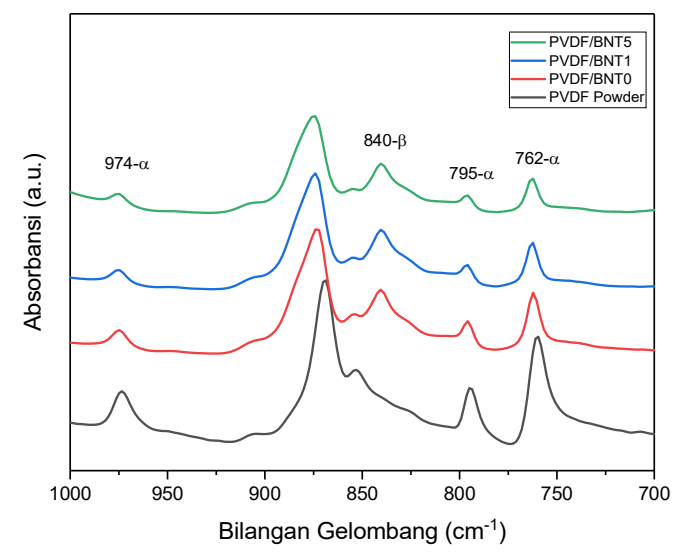

Gambar 3. Spektra FTIR PVDF murni dan membran hibrida PVDF/BNT.

\section{Analisis Pelelehan dan Kristalisasi Membran Hibrida PVDF/BNT}

Termogram DSC dan data detail proses pelelehan membran PVDF dan membran hibrida PVDF/BNT ditunjukkan pada Gambar 4. Data menunjukkan proses inisiasi pelelehan polimer PVDF pada sampel serbuk PVDF mengalami inisiasi pelelehan pada suhu yang lebih rendah yaitu pada $125^{\circ} \mathrm{C}$ dan diperoleh puncak titik leleh pada $175{ }^{\circ} \mathrm{C}$. Pada sampel membran PVDF maupun hibridanya mengalami pergeseran ke suhu inisiasi pelelehan yang lebih tinggi yaitu sekitar $142{ }^{\circ} \mathrm{C}$ sampai $145^{\circ} \mathrm{C}$. Keberadaan lempung dan pembentukan fasa $\alpha$ dan $\beta$-PVDF pada matriks membran mempengaruhi titik puncak pelelehan (melting point - Tm). Gambar 4 menunjukkan bahwa pembentukan fasa $\beta$-PVDF dalam matiks membran meningkatkan suhu inisiasi pelelehan, namun menurunkan Tm membran dibandingkan serbuk PVDF yang didominasi oleh fasa $\alpha$ PVDF. Membran PVDF dan hibridanya diperoleh Tm berturut-turut $170{ }^{\circ} \mathrm{C}, 171{ }^{\circ} \mathrm{C}, 173{ }^{\circ} \mathrm{C}$ dan $170^{\circ} \mathrm{C}$ untuk penambahan BNT $0 \%, 1 \%, 3 \%$ dan $5 \% \mathrm{~b} / \mathrm{b}$. Pembentukan polimorf PVDF karena adanya BNT pada matriks membran juga mempengaruhi rentang suhu pelelehan. Data menunjukkan terjadinya penurunan rentah suhu pelelehan, dan ini mengindikasikan semakin homogen jenis fasa PVDF yang terbentuk pada matriks membran. Detail keberadaan fasa polimorf PVDF pada proses pelelehan dibahas pada hasil dekonvolusi DSC masing-masing sampel.

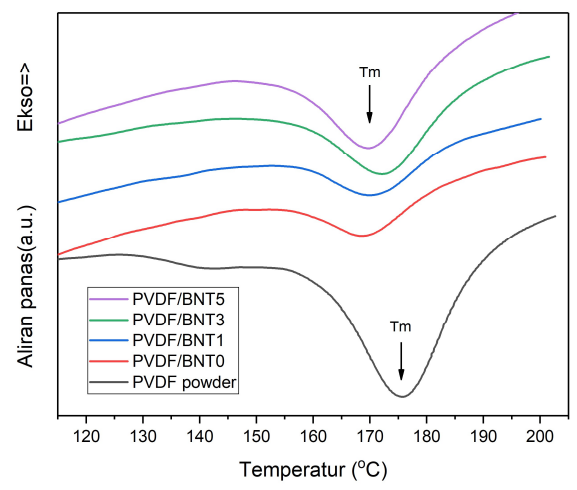

Gambar 4. Termogram DSC serbuk PVDF dan membran hibrida PVDF/BNT. 

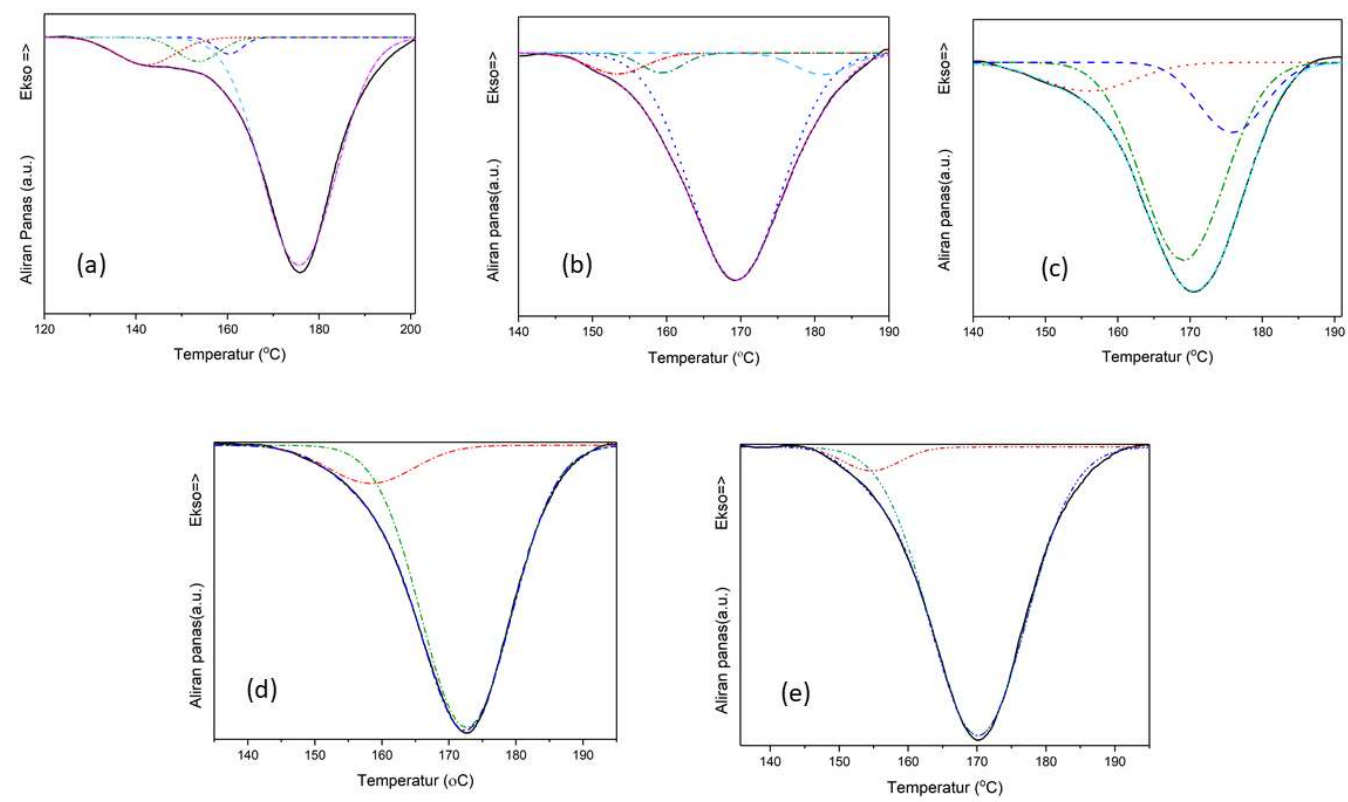

Gambar 5. Dekonvolusi termogram DSC membran (a) PVDF/BNT0, (a) PVDF/BNT1, (c) PVDF/BNT5.

Analisis komprehensif data DSC proses pelelehan dilakukan dengan dekonvolusi data dan hasilnya ditunjukkan pada Gambar 5. Data menunjukkan adanya perbedaan pola pelelehan pada serbuk PVDF, membran PVDF tanpa BNT dan membran hibrida PVDF/BNT. Dekonvolusi termogram DSC serbuk PVDF dan membran PVDF tanpa BNT tersusun atas empat puncak. Sementara itu, pada membran hibrida PVDF/BNT diperoleh tiga puncak pada penambahan BNT $1 \% \mathrm{~b} / \mathrm{b}$ dan dua puncak untuk penambahan BNT 3\% dan 5\% b/b. Dengan adanya BNT pada larutan cetak mengakibatkan adanya reorientasi struktur PVDF di permukaan aluminosilika lempung saat terjadinya nukelasi (Zhang et al., 2012). Proses tersebut mengakibatkan PVDF yang terbentuk relatif seragam sehingga menghasilkan titik leleh dengan rentang lebih kecil dan tidak diperoleh punggung pasca Tm. Fasa $\alpha-$ PVDF dan $\beta$-PVDF diketahui memiliki titik leleh yang relatif berdekatan (Ruan et al., 2018; Tao et al., 2013), oleh karena itu pada penelitian ini pun diperoleh puncak yang relatif bertumpang tindih, namun pada membran PVDF tanpa BNT munculnya punggung pasca Tm berhubungan dengan pelelehan segmen $\beta$ PVDF.

Proses kristalisasi polimer PVDF dipengaruhi oleh pelarut, kondisi koagulan dan zat yang ditambahkan (Ike et al., 2017; Tao et al., 2013; Zhang et al., 2012). Kristalinitas relatif dari masing-masing matriks PVDF yang terbentuk pada membran dapat diketahui dari total perubahan eltalpi pelelehannya dan dibandingkan dengan entalpi 100\% kristalin PVDF yaitu sebesar 104,7 J/g (Marega and Marigo, 2003). Data entalpi pelelehan dan persen kristalinitas (Xc) ditunjukkan pada Tabel 1. Data menunjukkan kristalinitas membran lebih kecil dibandingkan dengan serbuk PVDF. Kristalisasi matriks PVDF pada membran terjadi pada proses koagulasi dalam inversi fasa. Larutan polimer yang bersuhu kurang lebih $50^{\circ} \mathrm{C}$ didinginkan mendadak pada suhu koagulan $25^{\circ} \mathrm{C}$, sehingga polimer PVDF cenderung terbentuk fasa amorf. Variasi konsentrasi BNT mempengaruhi kristalinitas membran dan semakin besar konsentrasi BNT menghasilkan kristalinitas yang semakin tinggi pula. Seperti dijelaskan sebelumnya, keberadaan BNT membantu mengarahkan struktur PVDF pada proses kristalisasi, sehingga dengan makin tingginya BNT kristalinitas PVDF pada matriks membran makin besar pula.

Tabel 1. Data entalpi pelelehan dan kristalinitas PVDF dan membran hibrida PVDF/BNT.

\begin{tabular}{lll}
\hline Sampel & $\mathbf{\Delta H m}(\mathbf{J} / \mathbf{g})$ & $\mathbf{X c}(\mathbf{\%})$ \\
\hline PVDF powder & 39,65 & 37,87 \\
PVDF/BNT0\% & 18,21 & 17,39 \\
PVDF/BNT1\% & 17,50 & 16,71 \\
PVDF/BNT3\% & 20,44 & 19,52 \\
PVDF/BNT5\% & 27,09 & 25,87 \\
\hline
\end{tabular}


Analisis lanjut dilakukan pada proses kristalisasi pasca pelelehan dengan DSC dan termogram DSC ditunjukkan pada Gambar 6. Proses kristalisasi terjadi saat sampel didinginkan setelah melalui tahapan pelelehan, dan ditandai dengan puncak eksotermik pada termogram DSC. Gambar 6 menunjukkan bahwa polimer PVDF mengalami kristalisasi pada proses pendinginan dan penambahan BNT mengakibatkan proses kristalisasi terjadi lebih awal atau pada suhu yang lebih tinggi. Dari data diperoleh titik onset membran hibrida PVDF BNT 5\% b/b terjadi pada $150{ }^{\circ} \mathrm{C}$, sementara pada sampel serbuk polimer diperoleh onset kristalisasi pada $143{ }^{\circ} \mathrm{C}$.

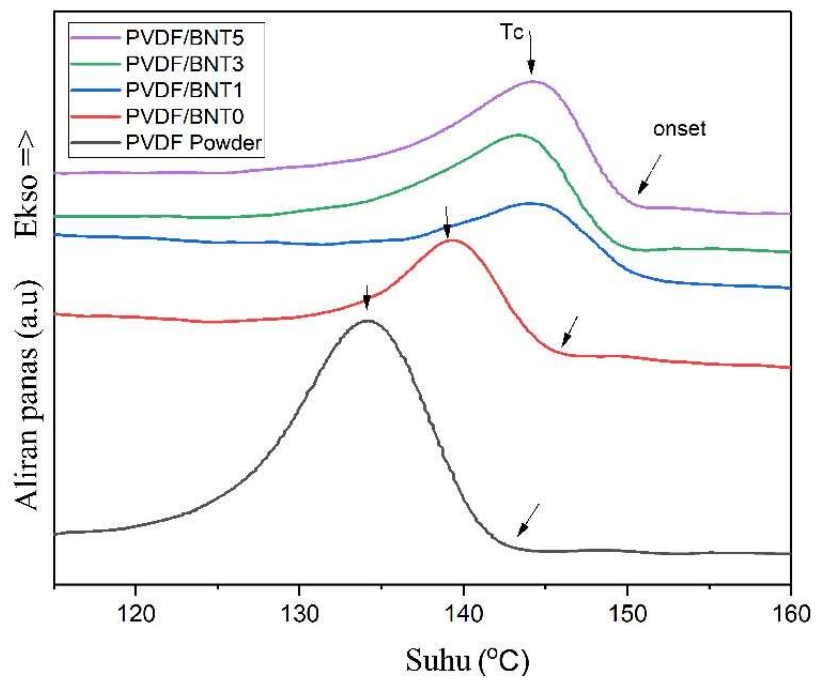

Gambar 6. DSC termogram kristalisasi serbuk PVDF dan membran hibrida PVDF/BNT

Nilai titik puncak kristalisasi (Tc) berbeda cukup besar antara serbuk PVDF dan membran hibrida PVDF/BNT, yaitu diperoleh Tc untuk serbuk PVDF, membran hibrida BNT 0\% dan $5 \%$ b/b berturut-turut pada $134{ }^{\circ} \mathrm{C}, 139{ }^{\circ} \mathrm{C}$ dan $144^{\circ} \mathrm{C}$. Dari data diperoleh perbedaan Tc mencapai 10 derajat Celsius antara sampel serbuk polimer PVDF dan membran hibrida dengan BNT 5\% b/b. Data termogram DSC kristalisasi menunjukkan bahwa polimer PVDF terkristalisasi secara isotermal atau terjadi pada suhu yang sama baik fasa $\alpha$ maupun $\beta$ - PVD untuk tiap jenis sampel uji. Hal ini ditunjukkan dengan pola puncak yang serempak dan tidak dihasilkan punggung. Kristalisasi pada PVDF dipengaruhi oleh kecepatan pendinginan (Pérez et al., 2020), pada kecepatan yang sama PVDF dan relatif tinggi cenderung mengalami kristalisasi isothermal, namun pada kecepatan yang lebih rendah proses kristalisasi akan terjadi non-isotermal (Liu et al., 1997).

Pada penelitian ini, proses pendinginan dilakukan secara otomatis oleh alat yaitu sekitar 30 derajat/menit dan tidak divariasikan pada kecepatan yang lebih rendah, sehingga kristalisasi terjadi secara iso-termal (Pérez et al., 2020). Kecepatan pedinginan yang tinggi mengakibatkan proses relaksasi segmen polimer tidak terjadi sehingga cenderung terbentuk satu jenis kristal, sementara pada pendinginan dengan kecepatan lebih rendah proses relaksasi segmen polimer memungkinkan terjadi dan struktur polimorf fasa $\alpha$ dan $\beta$-PVDF dapat terbentuk pada suhu yang berbeda.

Analisis perubahan aliran panas pembentukan kristal PVDF terhadap suhu pendinginan dilakukan dengan menurunkan data aliran panas terhadap suhu (T) dan hasilnya ditunjukkan pada Gambar 7. Sampel serbuk PVDF menghasilkan intensitas nilai yang lebih tinggi dibandingkan membran hibrida PVDF/BNT. Hasil intensitas lebih tinggi diperoleh pada membran PVDF BNT0 dan 5\% dibandingkan pada penambahan 1 dan $3 \%$ b/b. Hal ini menunjukkan bahwa dalam proses kristalisasi serbuk PVDF dan membran PVDF tanpa BNT melepaskan energi yang lebih besar untuk setiap 1 atau memiliki kapasitas kalor $(\mathrm{Cp})$. Penambahan BNT yang cukup besar berdampak pula pada pelepasan energi tersebut, dan hal ini berkorelasi dengan kristalinitas matriks PVDF. Dari data tampak bahwa dalam proses pendinginan, tanpa adanya BNT polimorf fasa $\alpha$ dan $\beta$-PVDF terkristalkan lebih baik dari lelehannya. Membran hibrida dengan penambahan lempung menunjukkan peningkatan intensitas dengan semakin besar konsentrasi BNT. Hal ini menunjukkan pada konsentrasi rendah, tolakan polar - non polar antara PVDF dan BNT masih terjadi sehingga kemampuan kristalisasi PVDF menurun, namun dengan semakin besarnya konsentrasi 
BNT justru membantu mengarahkan struktur dan meningkatkan kembali pembentukan kristal PVDF khususnya fasa $\beta$-PVDF yang lebih bersifat polar.

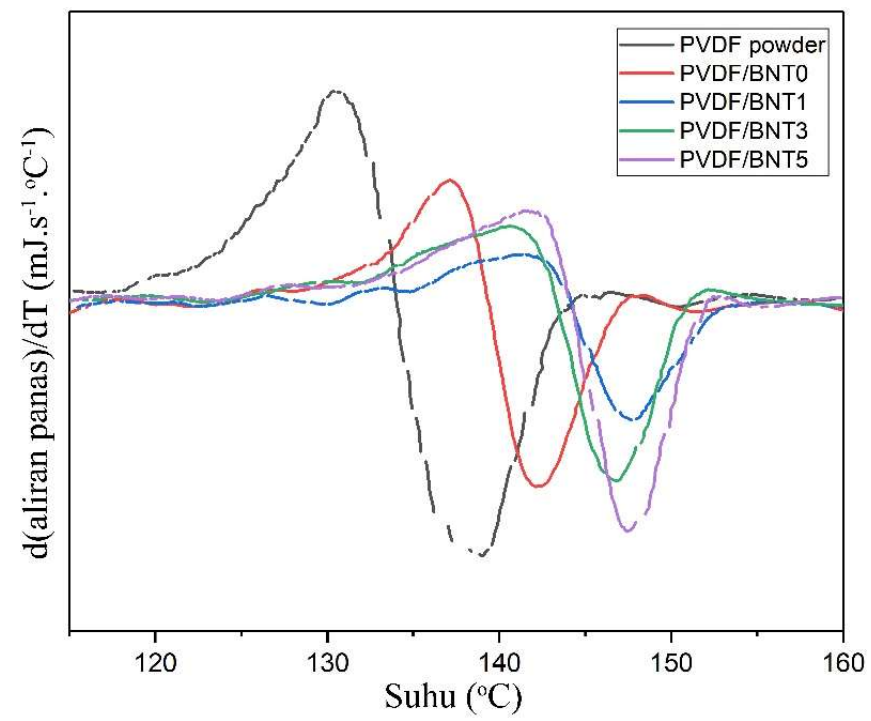

Gambar 7. Perubahan aliran panas terhadap suhu pada kristalisasi serbuk PVDF dan membran hibrida $\mathrm{PVDF} / \mathrm{BNT}$.

\section{KESIMPULAN}

Membran hibrida PVDF/BNT telah berhasil dibuat menggunakan metode inversi fasa, dan dianalisis struktur serta sifat termalnya. Analisis struktur menunjukkan bahwa membran yang dihasilkan tersusun atas campuran fasa $\alpha$-PVDF dan $\beta$-PVDF yang dikonfirmasi oleh data XRD dan ATR-FTIR pada puncak khas masing-masing fasa. Analisis termal dengan DSC memberikan informasi pelelehan dan kristalisasi PVDF yang dipengaruhi oleh keberadaan BNT dan pembentukan fasa $\alpha$-PVDF dan $\beta$-PVDF. Data menunjukkan bahwa keberadaan BNT yang menginduksi pembentukan fasa $\beta$-PVDF menurunkan titik leleh membrane dibandingkan dengan PVDF serbuk yang tersusun oleh fasa $\alpha$-PVDF. Sehingga, adanya BNT pada larutan cetak membantu meningkatkan kristalinitas membran PVDF, yang didominasi oleh segmen fasa $\beta$-PVDF yang relatif polar di permukaannya. Analisis DSC menunjukkan kinerja yang baik dalam analisis komprehensif sifat kristal PVDF pada matriks membran yang terbentuk dari proses inversi fasa maupun proses kristalisasi pasca lelehannya.

\section{UCAPAN TERIMA KASIH}

Penulis mengucapkan terima kasih kepada KK Kimia Fisika dan Anorganik FMIPA ITB untuk fasilitas laboratorium dan penggunaan alat ATR-FTIR. Ucapan terima kasih juga kami sampaikan kepada LPPM UNS atas support finansial melaui Hibah Grup Riset 2020 No. 452/UN27.21/PN/2020.

\section{DAFTAR PUSTAKA}

Ahmadian-Alam, L., and Mahdavi, H., 2018. Preparation and Characterization of PVDF-Based Blend Membranes as Polymer Electrolyte Membranes in Fuel Cells: Study of Factor Affecting The Proton Conductivity Behavior. Polymers for Advanced Technologies 29, 2287-2299. doi: 10.1002/pat.4340.

Bai, H., Wang, X., Zhou, Y. and Zhang, L., 2012. Preparation and Characterization of Poly (Vinylidene Fluoride) Composite Membranes Blended with Nano-Crystalline Cellulose. Progress in Natural Science: Materials International 22(3), 250-257. doi: 10.1016/j.pnsc.2012.04.011.

Cai, X., Lei, T., Sun, D., and Lin, L., 2017. A Critical Analysis of the $\alpha, \beta$ and $\gamma$ Phases in Poly(Vinylidene Fluoride) Using FTIR. RSC Advances 7(25), 15382-15389. doi: 10.1039/c7ra01267e.

Cui, Z., Hassankiadeh, N.T., Zhuang, Y., Drioli, E. and Lee, Y.M., 2015. Crystalline Polymorphism in Poly (Vinylidenefluoride) Membranes. Progress in Polymer Science 51, 94-126. doi: 10.1016/j.progpolymsci.2015.07.007. 
Fadaei, A., Salimi, A., and Mirzataheri, M., 2014. Structural Elucidation of Morphology and Performance of the PVDF/PEG Membrane. Journal of Polymer Research 21(9), 545. doi: 10.1007/s10965-014-0545-X.

Ike, I. A., Zhang, J., Groth, A., Orbell, J. D., and Duke, M., 2017. Effects of Dissolution Conditions on the Properties of PVDF Ultrafiltration Membranes. Ultrasonics Sonochemistry 39, 716-726. doi: 10.1016/j.ultsonch.2017.05.041.

Lai, C. Y., Groth, A., Gray, S., and Duke, M., 2015. Impact of Casting Conditions on PVDF / nanoclay Nanocomposite Membrane Properties. Chemical Engineering Journal 267, 73-85. doi: 10.1016/j.cej.2014.12.036.

Lee, T. H., Lee, M. Y., Lee, H. D., Roh, J. S., Kim, H. W., and Park, H. B., 2017. Highly Porous Carbon Nanotube/Polysulfone Nanocomposite Supports for High-Flux Polyamide Reverse Osmosis Membranes. Journal of Membrane Science 539, 441-450. doi: 10.1016/j.memsci.2017.06.027.

Liu, Z., Maréchal, P., and Jérôme, R., 1997. Melting and Crystallization of Poly(Vinylidene Fluoride) Blended with Polyamide 6. Polymer 38(20), 5149-5153. doi: 10.1016/S0032-3861(97)00047-5.

Marega, C., and Marigo, A., 2003. Influence of Annealing and Chain Defects on the Melting Behaviour of Poly(Vinylidene Fluoride). European Polymer Journal 39(8), 1713-1720. doi: 10.1016/S00143057(03)00062-4.

Park, J. W., Wycisk, R., and Pintauro, P. N., 2015. Nafion/PVDF Nanofiber Composite Membranes for Regenerative Hydrogen/Bromine Fuel Cells. Journal of Membrane Science, 490, 103-112. doi: 10.1016/j.memsci.2015.04.044.

Pérez, E., Angulo, I., Blázquez-Blázquez, E., and Cerrada, M. L., 2020. Characteristics of the Non-Isothermal and Isothermal Crystallization for the $\beta$ Polymorph in PVDF by Fast Scanning Calorimetry. Polymers 12(11), 117. doi: 10.3390/polym12112708.

Polisetti, V., and Ray, P., 2021. Nano SiO2 and TiO2 Embedded Polyacrylonitrile/Polyvinylidene Fluoride Ultrafiltration Membranes: Improvement in Flux and Antifouling Properties. Journal of Applied Polymer Science 138(1), 1-21. doi: 10.1002/app.49606.

Pramono, E., Alfiansyah, R., Ahdiat, M., Wahyuningrum, D., and Radiman, C. L., 2019. Hydrophilic Poly(Vinylidene Fluoride)/Bentonite Hybrid Membranes for Microfiltration of Dyes. Materials Research Express 6, 105376. doi: 10.1088/2053-1591/ab42e9.

Ruan, L., Yao, X., Chang, Y., Zhou, L., Qin, G., and Zhang, X. 2018. Properties and Applications of the $\beta$ Phase Poly(Vinylidene Fluoride). Polymers 10(3), 1-27. doi: 10.3390/polym10030228.

Santos, W. N. dos, Iguchi, C. Y., and Gregorio, R., 2008. Thermal Properties of Poly(Vinilidene Fluoride) in the Temperature Range from 25 to $210^{\circ} \mathrm{C}$. Polymer Testing 27(2), 204-208. doi: 10.1016/j.polymertesting.2007.10.005.

Seraji, S. M., and Guo, Q., 2020. Polymorphism and Crystallization in Poly(Vinylidene Fluoride)/ Poly( $\epsilon-$ Caprolactone)-Block-Poly(Dimethylsiloxane)-Block-Poly(€-Caprolactone) Blends. Polymer International 69(2), 173-183. doi: 10.1002/pi.5933.

Tao, M. mi, Liu, F., Ma, B. rong, and Xue, L. xin., 2013. Effect of Solvent Power on PVDF Membrane Polymorphism During Phase Inversion. Desalination 316, 137-145. doi: 10.1016/j.desal.2013.02.005.

Tsonos, C., Pandis, C., Soin, N., Sakellari, D., Myrovali, E., Kripotou, S., Kanapitsas, A., and Siores, E., 2015. Multifunctional Nanocomposites of Poly(Vinylidene Fluoride) Reinforced by Carbon Nanotubes and Magnetite Nanoparticles. Express Polymer Letters 9(12), 1104-1118. doi: 10.3144/expresspolymlett.2015.99.

Yuan, X. S., Guo, Z. Y., Geng, H. Z., Rhen, D. S., Wang, L., Yuan, X. T., and Li, J., 2019. Enhanced Performance of Conductive Polysulfone/MWCNT/PANI Ultrafiltration Membrane in an Online Fouling Monitoring Application. Journal of Membrane Science 575, 160-169. doi: 10.1016/j.memsci.2019.01.010

Zhang, Y. Y., Jiang, S. L., Yu, Y., Xiong, G., Zhang, Q. F., and Guang, G. Z., 2012. Phase Transformation Mechanisms and Piezoelectric Properties of Poly(Vinylidene Fluoride)/Montmorillonite Composite. Journal of Applied Polymer Science 123(5), 2595-2600. doi: 10.1002/app.34431.

Zheng, J., He, A., Li, J., and Han, C. C., 2007. Polymorphism Control of Poly(Vinylidene Fluoride) Through Electrospinning. Macromolecular Rapid Communications 28(22), 2159-2162. doi: 10.1002/marc.200700544.

Zhu, J., Zhou, S., Li, M., Xue, A., Zhao, Y., Peng, W., and Xing, W., 2020. PVDF Mixed Matrix Ultrafiltration Membrane Incorporated with Deformed Rebar-like Fe3O4-Palygorskite Nanocomposites to Enhance Strength and Antifouling Properties. Journal of Membrane Science 612, 118467. doi: 10.1016/j.memsci.2020.118467. 